\title{
Atypical otolaryngologic manifestations of COVID-19: a review
}

\author{
Mohamed Zahran $^{1^{*}}$ (D), Rania Ghazy ${ }^{1}$, Omar Ahmed ${ }^{1,2}$ and Ahmed Youssef ${ }^{1}$
}

\begin{abstract} atypical presentations in otolaryngology were presented.

Keywords: Corona virus, COVID-19, SARS-CoV-2, Otolaryngology

\section{Background}

COVID-19 pandemic caused by SARS-CoV-2 started in China in late 2019 [1]. The main route of viral spread is through aerosol transmissions. As of today, 26 million persons got infected and 880,000 died of the disease [2].

COVID-19 has wide spectrum of clinical features starting from mild disease to severe illness. Incubation period ranges from 2 to 14 days. Common clinical features include fever, cough, rhinorrhea, dyspnea, and body ache. Other less common manifestations include nausea, vomiting, or diarrhea [3, 4].
\end{abstract}

Background: COVID-19 pandemic caused by SARS-CoV-2 started in China in late 2019. Clinical features include fever, cough, dyspnea, body aches, and gastrointestinal symptoms. Some COVID-19-positive patients presented with unusual manifestations such as olfactory dysfunction, parotitis, or cervical lymphadenopathy.

Main body: Since many patients are diagnosed with SARS-CoV-2, the need for an up to date review of the atypical ENT presentations of COVID-19 is mandatory. Articles from PubMed and Google searches were reviewed and the

Conclusions: It is crucial for ENT physicians to have high index of suspicion to identify those COVID 19 patients with atypical presentations. This facilitates early case isolation to eliminate viral spread across the community.

\section{Methods}

Source information was sought via PubMed and Google searches for "(coronavirus or COVID) and atypical presentations." Online content was specifically sought because of the very recent nature of many source documents.

\footnotetext{
* Correspondence: abdelnaby00@hotmail.com

${ }^{1}$ Department of Otolaryngology, Alexandria University School of Medicine,

Champllion Street, El-Azareeta, Alexandria, Egypt

Full list of author information is available at the end of the article
}

\section{Review methods}

All sources presenting objective evidence related to the topic were reviewed and filtered.

\section{Ethical considerations}

The study was approved by The Hospital Ethics Committee and informed consent was not mandatory.

\section{Results}

The spectrum of the atypical presentations of COVID19 in otolaryngology is summarized in Table 1 and presented in details in the following sections.

\section{COVID-19-induced acute otitis media}

Fidan [5] reported a case of COVID-19-induced acute otitis media (AOM) in 35-year-old female. The patient initially presented with otalgia and tinnitus and there were no other symptoms of COVID-19. Otoscopy revealed right red bulging tympanic membrane. Audiologic investigations demonstrated right conductive hearing loss and type B tympanometry. Due to the incidental finding of mild rhonchi and the current pandemic, chest $\mathrm{X}$-ray and RT-PCR were done. The result came as COVID-19 positive.

\section{Springer Open}

( ) The Author(s). 2021 Open Access This article is licensed under a Creative Commons Attribution 4.0 International License, which permits use, sharing, adaptation, distribution and reproduction in any medium or format, as long as you give appropriate credit to the original author(s) and the source, provide a link to the Creative Commons licence, and indicate if changes were made. The images or other third party material in this article are included in the article's Creative Commons licence, unless indicated otherwise in a credit line to the material. If material is not included in the article's Creative Commons licence and your intended use is not permitted by statutory regulation or exceeds the permitted use, you will need to obtain permission directly from the copyright holder. To view a copy of this licence, visit http://creativecommons.org/licenses/by/4.0/. 
Table 1 Atypical manifestation of COVID-19 in otolaryngology

\begin{tabular}{ll}
\hline Organ/subsite & Atypical manifestations \\
\hline Ear & 1. Acute otitis media \\
& 2.SNHL \\
Nose & Olfactory dysfunction \\
Oral cavity and oropharynx & 1.Taste dysfunction \\
& 2.Vesiculobullous lesions \\
& 3.Ulcers and blisters \\
& 4.Strawberry tongue (Kawasaki-like) \\
Lymph nodes & Cervical lymphadenopathy \\
Parotid gland & 1. Acute parotitis \\
& 2. Parotitis-like disease \\
Thyroid gland & Subacute thyroiditis \\
\hline
\end{tabular}

\section{Sensorineural hearing loss (auditory dysfunction)}

The first case of COVID-19-induced sensorineural hearing loss (SNHL) was reported in Thailand in an elderly female. The patient recovered from COVID-19 infection; however, the hearing loss did not improve [6].

The effect of COVID-19 is an interesting issue in audiology. Several viral infections can directly damage inner ear structures causing hearing loss. Typically, virusinduced hearing loss is sensorineural (SNHL). The proposed mechanisms involved in virus-induced SNHL include direct damage to inner ear or indirect damage through induction of autoimmune response [7, 8]. Previous studies on other coronavirus infection revealed brainstem involvement and suggested possible affection of the auditory neural pathway [6].

A recent study of the effect of COVID-19 on the inner ear structures was done. The author compared between asymptomatic COVID-19 PCR-positive cases and control subjects. The persons enrolled in the study were 20-50 years to rule out any age-related hearing loss. Exclusion criteria were symptomatic COVID-19 patients and past history of hearing loss. The high-frequency pure tone thresholds and TEOAE amplitudes were significantly worse in COVID-19 patients [9].

Cure et al. [10] suggested the possible mechanism of COVID-19-induced SNHL. The entry point of COVID-19 is the lung and gets inside the cell by penetrating to the angiotensin-converting enzyme 2 (ACE2) [11]. COVID-19 binds to the beta chain of hemoglobin, transported by blood, and can penetrate all tissues with ACE2 [12]. Binding of COVID-19 to ACE2 depends on cytosolic pH. Heavy infection in the elderly is facilitated by their low cytosolic $\mathrm{pH}$ [11, 13]. The brain, medulla oblongata and the hearing center in the temporal lobe all have plenty of ACE2 [14]. Viralinduced cytokine release leads to irreversible hearing loss (oxidative stress). Oxygen release from the infected RBCs is low leading to tissue hypoxia and further cellular damage. There is ACE2 in vascular smooth muscles and COVID-19 is known to increase thrombosis risk. The elderly have preexisting risk factors for thrombosis (hypertension, diabetes mellitus, atherosclerosis) and this risk is amplified by COVID-19. The hearing loss is probably irreversible as it involves damage to central neuroauditory structures [10].

\section{Smell and taste dysfunction}

Many physicians reported anosmia, with or without dysgeusia in patients with severe COVID-19 infection. The AAO-HNS and the British Association of Otorhinolaryngology are now recommending these symptoms to be added to the list of primary screening symptoms for COVID-19.

A multi-center European study done by Lechien et al. [15] reported 357 patients with COVID-19 olfactory dysfunction. In a study by Klopfenstein et al., 54 of 114 patients (47\%) with confirmed COVID-19 reported anosmia. Anosmia began $4.4 \pm 1.9$ days after infection onset. The mean duration of anosmia was $8.9 \pm 6.3$ days and $98 \%$ of patients recovered within 28 days. Eighty-five percent had dysgeusia and $28 \%$ presented with pneumonia [16].

The concept of anosmia after viral infection is known as post-infectious/post-viral olfactory loss. Different kinds of viruses can induce olfactory loss, including COVID-19 [17]. The exact mechanism is not fully understood. Viral infection of the olfactory system by neurotropic viruses is possible explanation [18]. However, this was not confirmed by neuroimaging studies or histopathological tissue specimens of the olfactory neuroepithelium [19].

\section{Cervical lymphadenopathy}

Presence of cervical lymphadenopathy or strawberry tongue in children can be part of Kawasaki-like disease. There is growing number of children reported with COVID-19-induced Kawasaki-like disease. Kawasaki disease is an acute self-limiting vasculitis of the medium size blood vessels and almost exclusively affects children. Kawasaki disease was first reported by Tomisaku Kawasaki in Japan [20]. The exact cause of Kawasaki disease remains unknown. The most accepted theory suggests an aberrant response of the immune system to unknown pathogens in genetically susceptible patients [21].

The American Heart Association diagnostic criteria include (fever for $\geq 5$ days plus four or more clinical criteria, including bilateral bulbar non-exudative conjunctivitis, changes of the lips or oral cavity, non-suppurative lateral cervical lymphadenopathy, polymorphic rash, erythema of the palms and soles, firm induration of the hands or feet, or both) [22]. Early recognition of this serious disease facilitates appropriate referral to the pediatrician.

\section{Oral manifestations in COVID-19}

Many viruses including COVID-19 can present with exanthematous lesions as oral ulcers or blisters. The pathogenesis is similar to aphthous fever, hand, foot, and mouth disease, and herpetic gingivostomatitis [23]. 
Painful palatal ulcers were reported in two male patients 56 and 58 years old. There were multiple small ulcers with an erythematous halo on the hard palate with unilateral distribution. The lesions were similar to a herpetic recurrent stomatitis; although, the patients had no past history of herpetic infection. Complete recovery occurred within 10 days. Another COVID-19 patient presented with inner lip blisters and desquamative gingivitis. Improvement occurred within 3 days of oral steroids [24]. Similar study reported occurrence of irregular asymptomatic tongue ulcer in COVID-19 positive female [25].

\section{Parotitis and parotitis-like disease}

Many viruses as rubella, influenza, and HIV have predilection for salivary glands including the parotid [26]. Parotitis was reported to occur in association with COVID-19 [27]. Authors from France reported parotitislike manifestations in three COVID-19-positive patients. They validated the occurrence of intraparotid lymphadenitis by MRI findings. Complete recovery of parotitis occurred within few days [28].

\section{Subacute thyroiditis in COVID-19}

The pathogenesis of subacute thyroiditis in the setting of viral infections like COVID-19 is unclear. The disease may be directly related the viral infection or indirectly as a result of post- viral inflammatory response in genetically susceptible persons [29].

Authors reported a case of subacute thyroiditis in an 18-year-old female with COVID-19. Clinical manifestations included pain, tenderness, and enlargement in the thyroid gland. No history of upper respiratory tract infection was present. Laboratory work up showed elevated T3 and T4. Other markers of inflammation as ESR, CRP, and leucocytic count were also elevated. Thyroid US revealed multiple diffuse hypoechoic areas. Complete recovery of inflammation and improvement of thyroid function occurred within 2 weeks of prednisone treatment [30].

\section{Conclusion}

It is crucial for ENT physicians to have high index of suspicion to identify those COVID-19 patients with atypical presentations. This facilitates early case isolation to eliminate viral spread across the community.

\footnotetext{
Abbreviations

AAO-HNS: American academy of otolaryngology-head and neck surgery; COVID-19: Corona virus disease; CRP: C-reactive protein; ESR: Erythrocyte sedimentation rate; ENT: Ear, nose, throat; MRI: Magnetic resonance imaging; ORL: Otorhinolaryngology; RT-PCR: Real-time polymerase chain reaction; RBCs: Red blood cells; SNHL: Sensorineural hearing loss; SARS-CoV-2: Severe acute respiratory syndrome caused by corona virus 2; TEOAE: Transient evoked otoacoustic emission
}

\section{Acknowledgements}

None

\section{Authors' contributions}

M Z: corresponding author; design of the study, data collection and interpretation, final approval of the manuscript; RG: data collection and interpretation, final approval of the manuscript, OA: data collection and interpretation, final approval of the manuscript A Y: data interpretation, manuscript drafting, revision and approval. All authors read and approved the final manuscript.

\section{Funding}

None

Availability of data and materials

Not applicable

Ethics approval and consent to participate

The Ethics Committee at Alexandria University Hospital approved this study (7/2020) and informed consent was not mandatory.

\section{Consent for publication}

Not applicable

\section{Competing interests}

The authors declare that they have no competing interests.

\section{Author details}

${ }^{1}$ Department of Otolaryngology, Alexandria University School of Medicine, Champllion Street, El-Azareeta, Alexandria, Egypt. ${ }^{2}$ East Kent University Hospital, National Health Trust, London, UK.

Received: 22 July 2020 Accepted: 12 January 2021

Published online: 21 January 2021

\section{References}

1. Zhu N, Zhang D, Wang W et al (2020) A novel coronavirus from patients with pneumonia in China, 2019. N Engl J Med 382:727-33.

2. World Health Organization (WHO). Coronavirus disease (COVID-19) Pandemic. https://www.who.int/emergencies/diseases/novelcoronavirus201 9. Accessed 13 Dec 2020

3. Wu Z, JM MG (2020 Feb 24) Characteristics of and important lessons from the coronavirus disease 2019 (COVID-19) outbreak in China: summary of a report of 72314 cases from the Chinese Center for Disease Control and Prevention. JAMA. https://doi.org/10.1001/jama.2020.2648

4. Chen N, Zhou M, Dong X, Qu J, Gong F, Han Y et al (2020) Epidemiological and clinical characteristics of 99 cases of 2019 novel coronavirus pneumonia in Wuhan, China: a descriptive study. Lancet 395:507-513

5. V. Fidan, New type of corona virus induced acute otitis media in adult, Am J Otolaryngol (2018), https://doi.org/https://doi.org/10.1016/j.amjoto.2020. 102487

6. Sriwijitalai W, Wiwanitkit V (2020) Hearing loss and COVID-19: a note [published online ahead of print, 2020 Apr 2]. Am J Otolaryngol::102473. https://doi.org/10.1016/j.amjoto.2020.102473

7. Adler SP (2005) Congenital cytomegalovirus screening. Pediatric Infectious Disease Journal 24(12):1105-1106

8. Budzilovich GN, Lieberman AN (1973) Herpes zoster oticus and facial paralysis (Ramsay Hunt syndrome). Clinicopathologic study and review of literature. J Neurol Sci 20(2):149-159

9. M.W.M. Mustafa, Audiological profile of asymptomatic Covid-19 PCR-positive cases, Am J Otolaryngol (2020), https://doi.org/https://doi.org/10.1016/j. amjoto.2020.102483

10. E. Cure and M.C. Cure, Comment on "Hearing loss and COVID-19: a note", Am J Otolaryngol (2018), https://doi.org/https://doi.org/10.1016/j.amjoto. 2020.102513

11. Cure E, Cumhur CM (2020, http://doi.org/) Comment on "Organ-protective Effect of Angiotensin-converting Enzyme 2 and its Effect on the Prognosis of COVID-19". J Med Virol. https://doi.org/10.1002/jmv.25848

12. Liu W, Li H. COVID-19: Attacks the 1-Beta Chain of Hemoglobin and Captures the Porphyrin to inhibit human heme metabolism ChemRxi 2020, https://doi.org/https://doi.org/10.26434/chemrxiv.11938173.v7 
13. Cure E, Cumhur Cure M. Angiotensin-converting enzyme inhibitors and angiotensin receptor blockers may be harmful in patients with diabetes during COVID-19 pandemic. Diab Metab Syndr 2020, https://doi.org/https:// doi.org/10.1016/j.dsx.2020.04.019

14. Krasniqi S, Daci A (2019) Role of the Angiotensin Pathway and its Target Therapy in Epilepsy Management. Int J Mol Sci 20:E726

15. Lechien JR, Chiesa-Estomba CM, De Siati DR, Horoi M, Le Bon SD et al (2020) Olfactory and gustatory dysfunctions as a clinical presentation of mild-to-moderate forms of the coronavirus disease (COVID-19): a multicenter European study. Eur Arch Otorhinolaryngol 277(8):2251-2261. https://doi.org/10.1007/s00405-020-05965-1 Epub 2020 Apr 6. PMID: 32253535; PMCID: PMC7134551

16. Klopfenstein T, Kadiane-Oussou NJ, Toko L, Royer PY, Lepiller Q, Gendrin V et al (2020) Features of anosmia in COVID-19. Med Mal Infect 50(5):436-439. https://doi.org/10.1016/j.medmal.2020.04.006 Epub 2020 Apr 17. PMID: 32305563; PMCID: PMC7162775

17. Suzuki M, Saito K, Min W-P, Vladau C, Toida K, Itoh H et al (2007) Identification of viruses in patients with postviral olfactory dysfunction. Laryngoscop 117: 272-277. https://doi.org/10.1097/01.mlg.0000249922.37381.1e

18. Xydakis MS, Mulligan LP, Smith AB et al (2015) Olfactory impairment and traumatic brain injury in blast-injured combat troops: a cohort study. Neurology 84:1559-1567

19. Xydakis MS, Belluscio $L$ (2017) Detection of neurodegenerative disease using olfaction. Lancet Neurol 16:415-416

20. Kawasaki T, Kosaki F, Okawa S, Shigematsu I, Yanagawa H (1974) A new infantile acute febrile mucocutaneous lymph node syndrome (MLNS) prevailing in Japan. Pediatrics 54:271-276

21. Shulman ST, Rowley AH (2015) Kawasaki disease: insights into pathogenesis and approaches to treatment. Nat Rev Rheumatol 11:475-482

22. McCrindle BW, Rowley AH, Newburger JW et al (2017) Diagnosis, treatment, and long-term management of Kawasaki disease: a scientific statement for health professionals from the American Heart Association. Circulation 135: e927-e999

23. Scully C, Samaranayake LP (2016) Emerging and changing viral diseases in the new millennium. Oral diseases 22(3):171-179

24. Martín Carreras-Presas C, Amaro Sánchez J, López-Sánchez AF, Jané-Salas E, Somacarrera Pérez ML (2020) Oral vesiculobullous lesions associated with SARS-CoV-2 infection. Oral Dis

25. Chaux-Bodard AG, Deneuve S, Desoutter A (2020) Oral manifestation of Covid-19 as an inaugural symptom? Journal of Oral Medicine and Oral Surgery 26(2):18

26. Elbadawi LI, Talley P, Rolfes MA, Millman AJ, Reisdorf E, Kramer NA et al (2018) Non-mumps viral parotitis during the 2014-2015 influenza season in the United States. Clin Infect Dis 67:493-501

27. Acute parotitis: a possible precocious clinical manifestation of SARS-CoV-2 infection? Otolaryngology-Head and Neck Surgery. 2020; 163(1):182-183. https://doi.org/10.1177/0194599820926992

28. Lechien JR, Chetrit A, Chekkoury-Idrissi Y, Distinguin L, Circiu M, Saussez S, et al (2020). Parotitis-Like Symptoms Associated with COVID-19, France, March-April 2020. Emerg Infec Dis 26(9):2270-1. https://dx.doi.org/10.3201/ eid2609.202059

29. Desailloud, R., \& Hober, D. Viruses and thyroiditis: an update. Virol J 6, 5 (2009). https://doi.org/https://doi.org/10.1186/1743-422X-6-5

30. Brancatella, A., Ricci, D., Viola, N., Sgrò, D., Santini, F., \& Latrofa, F. Subacute thyroiditis after SARS-CoV-2 infection. The Journal of Clinical Endocrinology \& Metabolism, Volume 105, Issue 7, July 2020, Pages 2367-2370, https://doi. org/https://doi.org/10.1210/clinem/dgaa276

\section{Publisher's Note}

Springer Nature remains neutral with regard to jurisdictional claims in published maps and institutional affiliations.

\section{Submit your manuscript to a SpringerOpen ${ }^{\circ}$ journal and benefit from:}

- Convenient online submission

- Rigorous peer review

- Open access: articles freely available online

High visibility within the field

- Retaining the copyright to your article

Submit your next manuscript at $\boldsymbol{\nabla}$ springeropen.com 